\title{
"The role of earnings management in the relationship between accruals and market value"
}

\author{
Nasim Aryannejad iD https://orcid.org/0000-0002-9714-0354 \\ AUTHORS \\ Mohammadhossein Ghaemi \\ Keyhan Maham
}

Nasim Aryannejad, Mohammadhossein Ghaemi and Keyhan Maham (2018). The

ARTICLE INFO role of earnings management in the relationship between accruals and market value. Investment Management and Financial Innovations, 15(1), 236-244. doi:10.21511/imfi.15(1).2018.20

DOI http://dx.doi.org/10.21511/imfi.15(1).2018.20

RELEASED ON Monday, 12 March 2018

RECEIVED ON

Saturday, 09 September 2017

ACCEPTED ON

Thursday, 18 January 2018

\section{LICENSE}

\section{$(\mathrm{cc})$ EY}

This work is licensed under a Creative Commons Attribution 4.0 International License

JOURNAL

"Investment Management and Financial Innovations"

ISSN PRINT $1810-4967$

ISSN ONLINE $1812-9358$

PUBLISHER

LLC "Consulting Publishing Company "Business Perspectives"

FOUNDER

LLC "Consulting Publishing Company "Business Perspectives"

NUMBER OF REFERENCES

21

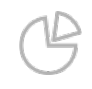

NUMBER OF FIGURES

0
NUMBER OF TABLES

9

(C) The author(s) 2022. This publication is an open access article. 


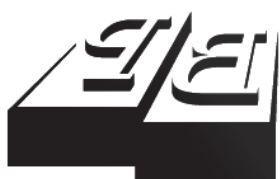

BUSINESS PERSPECTIVES

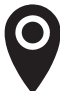

LLC "CPC "Business Perspectives" Hryhorii Skovoroda lane, 10, Sumy, 40022, Ukraine

www.businessperspectives.org

Received on: $9^{\text {th }}$ of September, 2017 Accepted on: $18^{\text {th }}$ of January, 2018

(C) Nasim Aryannejad,

Mohammadhossein Ghaemi,

Keyhan Maham, 2018

Nasim Aryannejad, Master of Accounting, Faculty of Accounting and Management, Islamic Azad University, Qazvin, Iran.

Mohammadhossein Ghaemi, Associate Professor, Faculty of Social Sciences, Imam Khomeini International University, Qazvin, Iran.

Keyhan Maham, Assistant Professor, Faculty of Accounting and Management, Islamic Azad University, Qazvin, Iran.

\section{() (i)}

This is an Open Access article, distributed under the terms of the Creative Commons Attribution 4.0 International license, which permits unrestricted re-use, distribution, and reproduction in any medium, provided the original work is properly cited.
Nasim Aryannejad (Iran), Mohammadhossein Ghaemi (Iran),

Keyhan Maham (Iran)

\section{THE ROLE OF EARNINGS MANAGEMENT IN THE RELATIONSHIP BETWEEN ACCRUALS AND MARKET VALUE}

\section{Abstract}

The paper aims to clarify the role of earnings management in the relationship between accruals and the market value of companies. Previous studies suggest that some managers, for providing a desirable image of their performance, manage their profits through distorting cash or accruals. Consequently, investors rely on this information and estimate inaccurate stability of accruals which lead to mispricing phenomenon. Finally, the returns earned by the investors will not be equal to the expected return and thus the accrual anomaly will be created.

To this aim, two hypotheses were developed and three regression models were applied to analyze the data. To analyze and estimate the models employed, the financial information of 110 companies listed on the stock exchange between years 2008 to 2014 is used. A selective approach to test the hypotheses is studying cross-sectional data.

After conducting statistical tests, the results showed that discretionary accruals through which earnings management is done are improperly valued by the market, but the issue is not applicable regarding the non-discretionary accruals. Based on the close relationship between earnings management and discretionary accruals it can be found that earnings management can have an effect on the relationship between accruals and market value.

Keywords

earnings management, total accruals, market value, accrual anomaly

JEL Classification M41, M40, G17, G19

\section{INTRODUCTION}

Sloan (1996) separated the company earnings into cash and accruals earnings, and showed that accruals earning have less stability in predicting future earnings and presented evidence that investors overprice their future accruals. As a result, they incorrectly evaluate the stock value due to errors in the assessment of earnings. A number of studies have shown that excess valuation of the whole accruals is the result of excess valuation of discretionary accruals that seems to be originated from managerial discretion.

According to earnings management theory, companies with accruals may opportunistically use accruals for inflating the future earnings. Investors tend to assume their reported profits steady. Ignoring the manipulation of earnings will guide the company to an unjustified optimistic performance. Since accruals are accounting adjustments for cash flows, the total of which should be negative over the life of the company, then high accruals in a period will reverse in future periods, and since the earnings are made of two components of cash and accruals, subsequently reverse accruals, future profits will shrink. Thus, 
according to the hypotheses accruals will shrink the future earnings. Thus based on the earnings management and stability of accruals, there is a negative relationship between accruals with future earnings (Hribar \& Collins, 2002).

Sloan (1996) found a negative relationship between accruals and future stock returns and called this negative relationship as accrual anomaly. He mentioned that the cause of such relationship is the existence of inexperienced investors in the market. The establishment of this relationship shows the incorrect reaction of investors towards changes in accruals. He deduced that market is ignorant in using and combining all the isolated information on the earning components.

Given the importance of the financial statements and their role in the decision-making of investors and creditors, we will deal with the role of earnings management in the relationship between accruals and market value.

\section{LITERATURE REVIEW}

It was after the studies of Sloan (1996) on incorrect pricing of accruals that other researchers such as Collins and Haribar (2002), Deasia et al. (2004) and Mashruwala (2006) who conducted several studies trying to complete this topic.

Findings of Sloan indicated the inability of the market to reflect the correct information of the accruals in stock prices. As a result, market overestimates the stability of earning accrual components and this has led to a negative relationship between accruals and the company's market value.

Hirshleifer et al. (2012), while investigating the accrual anomaly in 15 developed European markets, found that negative relationship between accruals and stock returns could be the result of accounting distortions. They also found that the impact of accounting distortions in the pricing earning accrual components in markets with high reliability and low secrecy is further and more powerful.

Among similar research, we can refer to the article of Ozkan et al. (2015), which dealt with the effect of accruals and cash flows information about future earnings on the stock price on the Istanbul Stock Exchange with a half-efficient market. In a case including both profitable and unprofitable companies, the valuation of accruals was reasonably done. By eliminating unprofitable companies from the sample, they specified the incorrect valuation of total accruals and its components in profitable companies, they also found evidence indicating accrual anomaly, which had results similar to studies by Dupuch et al. (2010) and Li et al. (2011).

Investigating profitable companies in the Chinese stock market, Li et al. (2011) found that investors overestimated accruals stability and, therefore, deal with the overvaluation of accruals.

Pincus et al. (2007) found that earnings management is the main phenomenon behind the accrual anomaly (Li et al., 2011).

Scott et al. (2005) showed that accruals with less reliability lead to lower earnings. They do this by classifying based on the balance sheet and achieved no similar results. The results of their study showed that due to the incomplete prediction of investors, some unrealistic pricing of stocks and securities happen in companies.

Investigating the capital market during 25 years, Chan et al. (2006) showed that the accruals have an inverse relationship with future stock returns, i.e. profit increase along with high amounts of accruals that represent the low quality of earnings will follow the poor performance of the stock.

\subsection{Review of the relationship between accounting earnings and its components}

Regarding the importance of the role of accounting earnings and cash flow as an important source of each economic unit and their applicability 
in many financial decisions, such as evaluation models of securities, the accounting earning is divided into cash and accrual components. Accounting earning is measured on an accrual basis and hence, there is a difference between accounting earning and the reported operating cash flows in case of the statement of cash flows. Jones (1991) has identified the difference between earnings and operating cash flow as accruals.

Xie (2001) defined accruals in the form of the gap between operating cash flow and accounting earning. Sloan (1996) defined accruals as a change in non-cash working capital minus the cost of depreciation. Sloan's definition is originated from Healy's definition (1985).

Sloan (1996) states that accruals that have low reliability will result in lower steady earnings, while investors expect more steady earnings. So the lack of familiarity with this issue will lead to incorrect pricing of the stock. Sloan concluded that the high costs resulting from this lack of awareness is related to identifying the available unreliable information contained in the financial statements and since he showed that the components of earnings are less steady than the cash component. Therefore, investigating the cash and accrual components to avoid the high costs required by investors are deemed to be necessary.

Accruals are divided into two categories. Those accruals which are created in the business model of companies and their operating environment in which business unit management is not involved in their creation, and were created during commercial activities of the companies are called non-discretionary accruals. Another category of accruals is made due to choosing accounting methods, arbitrary assignments, managerial decisions and judgments and estimations which are called discretionary accruals.

In other words, the type and amount of these items can vary from each company to the other, because they are affected by the selective procedures and policies of the companies and the more the manager of a company is free to create them, it will be more likely that he uses these ac- cruals to affect the profits. This action is known as the phenomenon of earnings management (Francis et al., 2005).

Due to the management's ability in applying different accounting methods to manipulate and deviate the earnings from one's personal wishes through accruals and regarding the empirical evidence in this area, based on the informational content of such items, it is argued that the accruals can be used as an indicator to determine the improvement or deterioration of the company (Palepu et al., 2000).

\subsection{Review of the relationship between earnings management and accruals}

There is no clear, agreed definition of accounting literature of earnings management. Because the border between earnings management and financial fraud is not specified. Schipper (1989) defines earnings management as 'earnings management is deliberate interference in external financial reporting process with the intention to gain profit'. Healy and Wahlen (1999) believe that earnings management occurs when managers use their personal judgment in financial reporting and manipulate the structure of transactions to create changes in financial reporting. This is done to mislead some benefit owners regarding the economic performance of the company or affect the results of contracts, the conclusion of which is subject to achieving personal profit.

The orientation of profitability could be changed due to maximizing the manager's utility, which is mentioned as job security. Following this definition, achieving increasing or steady profit flow will maximize the manager's utility. This approach is based on the expectation that management is able to improve or maintain past levels of profitability. If this expectation is not met by actual performance, the incentive to manipulate the financial statements will be provided (Summers \& Sweeney, 1998).

One of the most important events in the discussion of earnings management is discovering the difference in the stability between accrual and 
cash components. Sloan showed that according to the model of predicting the profitability of companies, the stability of the accrual component is less than the cash component. This finding was interpreted as evidence of the management of earning accrual component by scientists; and was associated with this implicit claim that managers manage earnings using discretionary accruals. As a result, the assumption is proposed that earnings management affects market perceptions of valuing normal accrual (unmanaged) and abnormal accrual (managed).

\subsection{Review \\ of the relationship between accruals and stock returns}

To evaluate the performance of business units, various criteria have been proposed so far, including return on stocks which is currently the most common criteria for evaluating the performance and profitability of enterprises. Nearly four decades of regular and systematic investigation of the effects of accounting information and stock returns is passing.

One of the topics of interest for the accounting researchers is the role of the accrual in market value of companies. Research related to this issue has been done by various researchers since 1990s. In 1996, Sloan showed that accruals are reflected in the value of shares unexpectedly or abnormally (Li et al., 2011).

Sloan (1996), and many subsequent studies following the issue of accruals stability argue that investors when forming their expectations from profit, tend to overevaluate the stability of accruals and underevaluate stability of cash flows. As a result, in companies with high accruals, the real returns are less than the expected returns that will surprise stockholders. So they conclude that low reliability of accruals leads to low stability of accruals resulting in a negative relation between accruals and future stock returns, which is called accruals anomaly, and they believe that the cause of this negative relationship is the existence of inexperienced investors in markets that fail to recognize the stability of accruals. According to the above descriptions, it is hypothesized that market investors have no understanding of accruals.

\section{RESEARCH TOOL AND METHODS}

\subsection{Research hypotheses}

In order to achieve the objectives of the research and investigating the role of earnings management in the relationship between accruals anomaly and the market value of companies, the research hypotheses can be expressed as follows.

H1: The market has a clear understanding of the valuation of company's accruals.

H2: Earnings management has an effect on the market understanding of the valuation of normal accruals and abnormal accruals.

\subsection{Research methodology}

In terms of classifying research and regarding data collection, this study is considered as descriptive correlation. This research is applied in terms of purpose and in terms of nature and its required information; the present research is cross-sectional approach analysis.

Hypotheses of the research are tested using the ranking model concerning each of the variables including the total accruals, operating cash flows, net income and future stock returns. Ranking models of this study have dealt with the linear relationship between the variables.

The study population of the research consisted of companies listed on the Tehran Stock Exchange and the territory of the research consisted of a 7-year period, based on published reports from 2008 to 2014

\subsection{Research models}

To investigate the hypotheses, we first need to separate both normal and abnormal accruals. To this purpose, model number (1) is used: 


$$
\begin{aligned}
& A C C_{i, t}=\beta_{0}+\beta_{1} \frac{1}{T A_{i, t-1}}+ \\
& +\beta_{2} \frac{\Delta \operatorname{Re} v}{T A_{i, t-1}}+\beta_{3} \frac{P P E}{T A_{i, t-1}}+\varepsilon_{i, t} .
\end{aligned}
$$

In the above formula, $T A_{i, t-1}$, is the total assets of the company at the beginning of each period, $\Delta \operatorname{Re} v_{t}$ is the change in sales revenues and $P P E_{t}$ is gross property, planet, and equipment for year $t$.

It should be noted that in the above model, for synchronization parameters to reduce the oscillations, the total assets of the company at the beginning of each period is used, and if non-discretionary accruals (NDA) are deducted from accruals, discretionary accruals will be obtained. So discretionary accruals are calculated using the Jones model as follows:

$$
\begin{aligned}
& A B A C C=A C C-\bar{\beta}_{0}-\bar{\beta}_{1}\left(\frac{1}{T A_{i, t-1}}\right)- \\
& -\bar{\beta}_{2}\left(\frac{\Delta \operatorname{Re} v}{T A_{i, t-1}}\right)-\bar{\beta}_{3}\left(\frac{P P E}{T A_{i, t-1}}\right) .
\end{aligned}
$$

And to calculate normal accruals:

$$
N A C C=A C C-A B A C C .
$$

Then in order to investigate the second hypothesis, Mishkin test is used. We need to simultaneously estimate the two models.

$$
\begin{aligned}
& E A R N_{i, t+1}=\beta_{0}+\beta_{1} A C C_{i, t}+ \\
& +\beta_{2} C F O_{i, t}+\varepsilon_{i, t+1}, \\
& S A R_{i, t+1}=\delta\left(E A R N_{i, t+1}-\beta^{*}{ }_{0}-\right. \\
& \left.-\beta^{*}{ }_{1} A C C_{i, t}-\beta_{2}^{*} C F O_{i, t}\right)+\varepsilon_{i, t+1} .
\end{aligned}
$$

In formulae (4) and (5), $E A R N_{i, t+1}$ is earnings forecast for next year, $A C C_{i, t}$ is the difference between earnings and cash from operations, and $C F O_{i, t}$ is cash from operations or net cash flow from operating activities.

As Mishkin (1983) and subsequent research, we estimate equations (4) and (5) jointly using an iterative generalized non-linear least squares estimation procedure. Mishkin (1983) shows that the likelihood-ratio statistic in (6) is asymptotically $\chi^{2}(q)$ distributed.

$$
2 \cdot N \cdot \ln \frac{S S R^{c}}{S S R^{u}}
$$

where $Q$ is the number of constraints imposed by market efficiency; $n$ is the number of sample observations; $S S R^{c}$ is the sum of squared residuals from the constrained regressions in the second

\begin{tabular}{|c|c|c|}
\hline Model & Variable & Remarks \\
\hline 4 & Earnt & Net income \\
\hline 4 & CFOt & Cash flows from operations \\
\hline 4 & ACCRt & Total accruals \\
\hline 1 & TAt-1 & $\begin{array}{l}\text { Total assets at the beginning } \\
\text { of financial period }\end{array}$ \\
\hline 1 & $\triangle \mathrm{REV}$ & The change in sales revenues \\
\hline 1 & PPEt & $\begin{array}{l}\text { Gross property, plant and } \\
\text { equipment }\end{array}$ \\
\hline 5 & SARi,t+1 & $\begin{array}{l}\text { Annual size adjusted abnormal } \\
\text { return }\end{array}$ \\
\hline
\end{tabular}
stage; and $S S R^{u}$ is sum of the squared residuals from the first-stage unconstrained regressions.

We reject the rational pricing of accruals and cash flows when the likelihood-ratio statistic (6) is sufficiently large.

\subsection{Variable definitions}

In Table 1, the method for calculation of research variables is shown.

Table 1. Definitions of the used variables

\section{RESULTS}

\subsection{Descriptive statistics}

Descriptive statistics of the variables are presented in Table 2.

\subsection{The first hypothesis test results}

In order to measure the first hypothesis, Mishkin test was used. Following the studies of Sloan (1996), for the Mishkin model, it is necessary to simultaneously estimate models (4) and (5) in 
Table 2. Descriptive statistics

\begin{tabular}{l|c|c|c|c|c|c}
\hline Variable & Mean & Median & VAR & SD & Min & Max \\
\hline EARNt & $0 / 182$ & $0 / 149$ & $0 / 222$ & $0 / 149$ & $-0 / 22$ & $0 / 664$ \\
CFOt & $0 / 165$ & $0 / 154$ & $0 / 029$ & $0 / 172$ & $-0 / 351$ & $0 / 694$ \\
ACCRt & $0 / 015$ & $-0 / 004$ & $0 / 228$ & $0 / 151$ & $-0 / 402$ & $0 / 53$ \\
ABACC & $0 / 008$ & $0 / 003$ & $0 / 016$ & $0 / 129$ & $-0 / 345$ & $0 / 458$ \\
NACC & $0 / 007$ & $-0 / 0006$ & $0 / 008$ & $0 / 089$ & $-0 / 268$ & $0 / 368$ \\
SARt+1 & $-0 / 002$ & $-0 / 009$ & $0 / 200$ & $0 / 447$ & $-0 / 968$ & $1 / 83$ \\
\hline
\end{tabular}

accordance with Xie (2001), Pincus et al. (2007), Dupach et al. (2010) (Ozkan \& Kayali, 2015).

To simultaneously estimate the two models, it is necessary to use simultaneous equations system, the results of which are presented in Table 3. It should also be noted that the first model is known as the prediction model, because this model deals with the investigation and prediction of the future earnings by its components, and the second model is named evaluation model, because in this mod$\mathrm{el}$, the initial model of prediction is evaluated and investigated by means of market (represented by the output variable and as the dependent variable), through which the market's understanding of stability coefficients and prediction of the earning components are evaluated. Furthermore, it must be stated that because the coefficient $\delta$ is calculated from transaction among other coefficients of available variables in the model, they are nonlinear models. Mishkin test is used after estimating the simultaneous equations for investigating the intended hypothesis. Mishkin test is known as rational expectations hypothesis, where one deals with market's perception of accounting variables. It is worth mentioning that the null and alternative hypotheses in Mishkin test are as follows:

The null hypothesis: There is no statistically significant difference between the limitations of the coeff- cients in evaluation and prediction models. In other words, the coefficients obtained in two models are statistically equal.

The alternative hypothesis: There is statistically a significant difference between the limitations of the coefficients in evaluation and prediction models. In other words, the coefficients obtained in the two models are statistically different.

In Table 3, the results of the simultaneous estimation of models (4) and (5) are provided.

Now given that in this hypothesis we dealt with the ability of the market to understand the stability of accruals, thus limitations in equations (4) and (5) are the simultaneous equality of accruals stability coefficient, in the two equations simultaneously. Mishkin test results are presented in Table 4.

Table 4. Mishkin test results

\begin{tabular}{c|c:c}
\hline Limitations & $\chi^{2}$ test & Probability \\
\hline$\beta_{1}=\beta_{1}^{*}$ & $4 / 497$ & $0 / 0339$ \\
\hline
\end{tabular}

According to the obtained results, it can be concluded that simultaneous equality of the two above limitations that set the error level of 5 percent is

Table 3. Results of the simultaneous estimation of models (4) and (5)

\begin{tabular}{|c|c|c|c|c|c|c|c|}
\hline \multicolumn{4}{|c|}{ Model (4) } & \multicolumn{4}{|c|}{ Model (5) } \\
\hline Coefficient & Quantity & $\begin{array}{c}\text { T-student } \\
\text { test }\end{array}$ & $\begin{array}{c}\text { Significance } \\
\text { level }\end{array}$ & Coefficient & Quantity & $\begin{array}{c}\text { T-student } \\
\text { test }\end{array}$ & $\begin{array}{c}\text { Significance } \\
\text { level }\end{array}$ \\
\hline$\beta_{0}$ & 0/056 & $6 / 34$ & 0/000 & $\beta_{0}^{*}$ & $0 / 176$ & $2 / 83$ & 0/005 \\
\hline$\beta_{1}$ & $0 / 558$ & $12 / 77$ & 0/000 & $\beta_{1}^{*}$ & $-0 / 138$ & $-0 / 423$ & 0/000 \\
\hline$\beta_{2}$ & $0 / 66$ & $16 / 89$ & 0/000 & $\beta_{2}^{*}$ & 0/039 & $0 / 133$ & 0/004 \\
\hline- & - & - & - & $\delta$ & $0 / 688$ & $3 / 51$ & 0/000 \\
\hline
\end{tabular}


rejected and we can say that the market has failed in a correct understanding of accrual stability. As a result, the first hypothesis is rejected. In other words, it can be said that the market valuation of accruals stability is different from its actual stability (with respect to the stability coefficient of the forecasting model) and the market makes an error in understanding the stability of the accruals.

\subsection{The second}

\section{hypothesis test results}

In order to investigate the second hypothesis, it is necessary to divide the total accruals into normal and abnormal parts. To do this, the model (1) is used, the results of which are presented below. Before fitting the model, in order to determine the method of estimation, the diagnostic test of Chow (F-Limer) was conducted to choose among the normally combined data methods against the panel data with fixed effects. The results are shown in Table 5.

Table 5. The result of $F$-Limer test

\begin{tabular}{c|c|c}
\hline Statistic & Error level & $\begin{array}{c}\text { Accepted } \\
\text { method }\end{array}$ \\
\hline $1 / 352$ & $0 / 232$ & $\begin{array}{c}\text { Normal combined } \\
\text { methods }\end{array}$ \\
\hline
\end{tabular}

Since the error level is obtained (0.232), which is more than acceptable level of 5 percent, the results showed the acceptance of $\mathrm{HO}$, thus common combined data approach is the preferred method. So in the following, the model estimation results are presented in Table 6 with conventional panel data.
Table 6. Results of Model (1) estimation

\begin{tabular}{|c|c|c|c|}
\hline Variable & Coefficient & T-student test & $\begin{array}{c}\text { Significance } \\
\text { level }\end{array}$ \\
\hline Y-intercept & 0/005 & $1 / 45$ & $0 / 147$ \\
\hline $1 / \mathrm{TA}$ & $824 / 78$ & $1 / 02$ & $0 / 308$ \\
\hline$\Delta \operatorname{Rev}$ & $0 / 124$ & $7 / 25$ & 0/000 \\
\hline PPE & $-0 / 071$ & $-7 / 19$ & 0/000 \\
\hline $\begin{array}{l}\text { Adjusted } \\
\text { R-squared }\end{array}$ & \multicolumn{2}{|c|}{ 0/092 } & \\
\hline $\begin{array}{l}\text { (Prob) } \\
\text { F-statistic }\end{array}$ & \multicolumn{2}{|c|}{ (0/000) 21/42 } & \\
\hline $\begin{array}{l}\text { Durbin- } \\
\text { Watson stat. }\end{array}$ & \multicolumn{2}{|c|}{$1 / 84$} & \\
\hline
\end{tabular}

According to the results in Table 6 according to statistics $F(21.42)$ and the error level obtained for it, which is equal to (0.000) and less than the error level of 0.01, therefore, at the confidence level of 0.99 , it can be stated that in general, the model is well fitted and highly significant. Also, according to the Durbin-Watson statistic value obtained, it can be concluded that there is no autocorrelation serial among the remaining sentences of the research model.

Now, it is necessary to calculate the normal and abnormal accruals with respect to the coefficients of the above model using models (2) and (3). In order to test the hypothesis, Mishkin test is used which involves simultaneous estimation of two prediction and evaluation models. The results of two models (4) and (5) estimation are provided in Table 7.

Table 7. Results of the simultaneous estimation of models (4) and (5)

\begin{tabular}{c|c|c|c|c|c|c|c}
\hline \multicolumn{4}{|c|}{ Model (4) } & \multicolumn{5}{c}{ Model (5) } \\
\hline Coefficient & Quantity & $\begin{array}{c}\text { T-student } \\
\text { test }\end{array}$ & $\begin{array}{c}\text { Significance } \\
\text { level }\end{array}$ & Coefficient & Quantity & $\begin{array}{c}\text { T-student } \\
\text { test }\end{array}$ & $\begin{array}{c}\text { Significance } \\
\text { level }\end{array}$ \\
\hline$\beta_{0}$ & $0 / 058$ & $6 / 65$ & $0 / 000$ & $\beta_{0}^{*}$ & $0 / 169$ & $2 / 83$ & $0 / 005$ \\
\hdashline$\beta_{1}$ & $0 / 649$ & $16 / 78$ & $0 / 000$ & $\beta_{1}^{*}$ & $0 / 059$ & $0 / 212$ & $0 / 832$ \\
\hdashline$\beta_{2}$ & $0 / 556$ & $11 / 69$ & $0 / 000$ & $\beta_{2}^{*}$ & $-0 / 273$ & $-0 / 756$ & $0 / 449$ \\
\hdashline$\beta_{3}$ & $0 / 514$ & $7 / 63$ & $0 / 000$ & $\beta_{3}$ & $0 / 351$ & $0 / 888$ & $0 / 375$ \\
\hline- & - & - & - & $\delta$ & $0 / 695$ & $3 / 56$ & $0 / 000$ \\
\hline
\end{tabular}


Given that in this hypothesis, we dealt with the investigation of the stability of the market's ability to understand normal and abnormal accruals, as a result, the mentioned equation has two limitations which are examined and showed in Tables 8 and 9.

Table 8. Mishkin test results related to abnormal accruals

\begin{tabular}{l:l:l}
\hline \multicolumn{1}{c}{ Limitations } & $\chi^{2}$ test & \multicolumn{1}{c}{ Probability } \\
\hline$\beta_{2}=\beta_{2}^{*}$ & $5 / 164$ & $0 / 023$ \\
\hline
\end{tabular}

According to the obtained results, it can be concluded that the simultaneous equality of the above limitation is rejected at the 5 percent level and we can say that the market is incapable of understanding the stability of abnormal accruals. In other words, it can be said that the market valuation of abnormal accruals stability is different from its actual stability (with respect to the stability coefficient related to the prediction model) and the market makes an error in understanding the stability of the accruals.

Table 9. Mishkin test results related to normal accruals

\begin{tabular}{c|c|c}
\hline Limitations & $\chi^{2}$ test & Probability \\
\hline$\beta_{3}=\beta_{3}^{*}$ & $0 / 167$ & $0 / 683$ \\
\hline
\end{tabular}

According to the obtained results, it can be said that simultaneous equality of the above limitation at the level of 5 percent is not rejected, and it can be said that the market doesn't have a correct understanding of the stability of normal accruals. In other words, it can be said that market valuation of stability of normal accruals is in accordance with its real stability (with respect to the stability coefficient related to the prediction model).

\section{CONCLUSION}

When we look more exactly at the components of accounting earnings and scrutinize it, we find that due to their estimation nature and not being objective, accruals can be abused by company stakeholders including managers. This is while the investors form their expected return on the basis of earnings information declared by companies. As a result, a lot of researches have dealt with the relationship between earnings, accruals and efficiency of the securities.

The results of the research show that the company does not have a true understanding of the accruals valuation. As a result, we can say that there is a relationship between accruals and market value of the companies, because if the accruals are not correctly valuated from the perspective of the market, then the expected returns of the investor will not be equal to the actual returns and this creates a negative and significant relationship between accruals and stock returns. Sloan (1996) called it accruals anomaly. Also, further investigations about the valuation of accruals components from the market showed that the market does not have a true understanding of discretionary accruals. But this is not true about nondiscretionary accruals, meaning that the market has a true understanding of the stability of accruals. Since discretionary accruals in earnings management are always used and manipulated by managers, we can realize the role of earning management in the relationship between accruals and market value of companies.

\section{REFERENCES}

1. Chan, K., Chan, L. K., Jegadeesh, N., \& Lakonishok, J. (2006).

Earnings quality and stock returns. Journal of Business, 79. https://doi.org/10.3386/w8308

2. Desai, H., Rajgopal, S., \& Venkatachalam, M. (2004).
Value-glamour and accruals mispricing: One anomaly or two? The Accounting Review, 79(2), 355-385. https://doi.org/10.2308/ accr.2004.79.2.355

3. Dopuch, N., Seethamraju, C., $\& \mathrm{Xu}, \mathrm{W}$. (2010). The pricing of accruals for profit and loss firms. Review of Quantitative Finance and Accounting, 34(4), 505516. http://dx.doi.org/10.2139/ ssrn.663514

4. Francis, J., LaFond, R., Olsson, P., \& Schipper, K. (2005). The market 
pricing of accruals quality. Journal of Accounting and Economics, 39(2), 295-327. https://doi. org/10.1016/j.jacceco.2004.06.003

5. Healy, P. M. (1985). The effect of bonus schemes on accounting decisions. Journal of Accounting and Economics, 7(1-3), 85-107. https://doi.org/10.1016/01654101(85)90029-1

6. Healy, P. M., \& Wahlen, J. M. (1999). A review of the earnings management literature and its implications for standard setting. Accounting Horizons, 13(4), 365-383. https://doi.org/10.2308/ acch.1999.13.4.365

7. Hirshleifer, D., Hou, K., \& Teoh, S H. (2012). The accrual anomaly: risk or mispricing? Management Science, 58(2), 320-335. https:// doi.org/10.2307/41406391

8. Hribar, P., \& Collins, D. W. (2002) Errors in estimating accruals: Implications for empirical research. Journal of Accounting Research, 40(1), 105-134. https:// doi.org/10.1111/1475-679X.00041

9. Jones, J. J. (1991). Earnings management during import relief investigations. Journal of Accounting Research, 29, 193-228. http://dx.doi.org/10.2307/2491047

10. Li, Y., Niu, J., Zhang, R., \& Largay, J. A. (2011). Earnings management and the accrual anomaly: Evidence from China. Journal of International Financial Management \& Accounting,
22(3), 205-245. https://

dx.doi.org/10.1111/j.1467646X.2011.01050.X

11. Mashruwala, C., Rajgopal, S., \& Shevlin, T. (2006). Why is the accrual anomaly not arbitraged away? The role of idiosyncratic risk and transaction costs. Journal of Accounting and Economics, 42(1), 3-33. http://dx.doi. org/10.1016/j.jacceco.2006.04.004

12. Minskin, F. (1983). A Rational Expectations Approach to Macroeconometrics. Chicago: University of Chicago Press for the National Bureau of Economic Research. Retrieved from http:// www.nber.org/books/mish83-1

13. Ozkan, N., \& Kayali, M. M. (2015). The accrual anomaly: Evidence from Borsa Istanbul. Borsa Istanbul Review, 15(2), 115-125. https://doi.org/10.1016/j. bir.2015.01.002

14. Palepu, K., Healy, P., \& Bernard, V. (2000). Business Analysis and Valuation (Southwestern Publishing). Retrieved from http://id.lib.harvard.edu/ aleph/010890495/catalog

15. Roychowdhury, S. (2006). Earnings management through real activities manipulation. Journal of Accounting and Economics, 42(3), 335-370. http:// dx.doi.org/10.2139/ssrn.477941

16. Schipper, K. (1989). Commentary on earnings management. Accounting Horizons, 3(4), 91-10.
Retrieved from http://connection. ebscohost.com/c/articles/4816073/ commentary-earningsmanagement

17. Scott, A., Sloan, R., Soliman, M., \& Tuna, I. (2005). Accrual reliability, earnings persistence and stock returns. Journal of Accounting Research, 39, 437-485. Retrieved from http://connection. ebscohost.com/c/articles/4816073/ commentary-earningsmanagement

18. Sloan, R. (1996). Do stock prices fully reflect information in accruals and cash flows about future earnings? (Digest summary). Accounting Review, 71(3), 289-315. Retrieved from http://www.jstor.org/stable/248290

19. Summers, S. L., \& Sweeney, J. T. (1998). Fraudulently misstated financial statements and insider trading: An empirical analysis. Accounting Review, 48, 131-146. Retrieved from http://www.jstor. org/stable/248345

20. Wu, J. G., Zhang, L., \& Zhang, X. (2010). The q-Theory Approach to Understanding the Accrual Anomaly. Journal of Accounting Research, 48(1), 177-223. https://doi.org/10.1111/j.1475679X.2009.00353.x

21. Xie, H. (2001). The mispricing of abnormal accruals. The Accounting Review, 76(3), 357-373. https://doi. org/10.2308/accr.2001.76.3.357 